\title{
Immune-related adverse events for anti-PD-1 and anti-PD-L1 drugs: systematic review and meta-analysis
}

\author{
Shrujal Baxi, ${ }^{1,2,3}$ Annie Yang, ${ }^{2}$ Renee L Gennarelli, ${ }^{2}$ Niloufer Khan, ${ }^{1}$ Ziwei Wang, ${ }^{4}$ Lindsay Boyce, ${ }^{5}$ \\ Deborah Korenstein ${ }^{1,2}$
}

${ }^{1}$ Department of Medicine,

Memorial Sloan Kettering

Cancer Center, 485 Lexington

Avenue, 2nd Floor, New York,

NY, USA

${ }^{2}$ Center for Health Policy and Outcomes, Memorial Sloan Kettering Cancer Center, New York, NY, USA

${ }^{3}$ Department of Medicine, Weill Cornell Medicine, New York, NY, USA

${ }^{4}$ Department of Medicine, University of Cailfornia LoS Angeles, Los Angeles, CA, USA

${ }^{5}$ Medical Library, Memorial

Sloan Kettering Cancer Center, New York, NY, USA

Correspondence to:

D Korenstein

korenstd@mskcc.org

Additional material is published online only. To view please visit the journal online.

Cite this as: $B M J$ 2018;360:k793 http://dx.doi.org/10.1136/bmj.k793

Accepted: 30 January 2018

\section{ABSTRACT}

OBJECTIVE

To evaluate rates of serious organ specific immunerelated adverse events, general adverse events related to immune activation, and adverse events consistent with musculoskeletal problems for anti-programmed cell death 1 (PD-1) drugs overall and compared with control treatments.

\section{DESIGN}

Systematic review and meta-analysis.

DATA SOURCES

Medline, Embase, Cochrane Library, Web of Science, and Scopus searched to 16 March 2017 and combined with data from ClinicalTrials.gov.

\section{STUDY SELECTION}

Eligible studies included primary clinical trial data on patients with cancer with recurrent or metastatic disease.

\section{DATA EXTRACTION}

Three independent investigators extracted data on adverse events from ClinicalTrials.gov and the published studies. Risk of bias was assessed using the Cochrane tool by three independent investigators. RESULTS

13 relevant studies were included; adverse event data were available on ClinicalTrials.gov for eight. Studies compared nivolumab $(n=6)$, pembrolizumab (5), or atezolizumab (2) with chemotherapy (11), targeted drugs (1), or both (1). Serious organ specific immunerelated adverse events were rare, but compared with standard treatment, rates of hypothyroidism (odds ratio $7.56,95 \%$ confidence interval 4.53 to 12.61$)$, pneumonitis (5.37, 2.73 to 10.56$)$, colitis $(2.88$,

\section{WHAT IS ALREADY KNOWN ON THIS TOPIC}

Drugs targeting programmed cell death 1 (PD-1) or its ligand (PD-L1) are being used more frequently to treat cancer

Proper clinical management requires understanding associated immune-related adverse events that can include organ specific adverse events, general adverse events related to immune activation, and adverse events consistent with musculoskeletal problems

Rates of these adverse events are unclear and publications from clinical trials may inconsistently report unexpected adverse events

\section{WHAT THIS STUDY ADDS}

Organ specific immune-related adverse events are uncommon with anti-PD-1 drugs but that risk is increased compared with control treatments

General adverse events related to immune activation such as fatigue are largely similar

Adverse events consistent with musculoskeletal problems are inconsistently reported but may be common
1.30 to 6.37$)$, and hypophysitis $(3.38,1.02$ to 11.08$)$ were increased with anti-PD-1 drugs. Of the general adverse events related to immune activation, only the rate of rash $(2.34,2.73$ to 10.56$)$ increased. Incidence of fatigue (32\%) and diarrhea (19\%) were high but similar to control. Reporting of adverse events consistent with musculoskeletal problems was inconsistent; rates varied but were over $20 \%$ in some studies for arthraligia and back pain.

CONCLUSIONS

Organ specific immune-related adverse events are uncommon with anti-PD-1 drugs but the risk is increased compared with control treatments. General adverse events related to immune activation are largely similar. Adverse events consistent with musculoskeletal problems are inconsistently reported but adverse events may be common.

\section{Introduction}

The development and rapid uptake of checkpoint inhibitors, a modern form of immunotherapy, has resulted in changes to the way numerous cancers are managed. In 2011, the Food and Drug Administration approved ipilumuab, an anti-cytotoxic T lymphocyte associated antigen 4 (CTLA-4). It was the first checkpoint inhibitor approved for the treatment of advanced melanoma, its only indication. Other checkpoint inhibitors directed at the programmed death 1 (PD-1) pathway are now approved for the treatment of multiple cancers. Anti-PD-1 drugs include monoclonal antibodies directed at both PD-1 (nivolumab and pembrolizumab) and the PD-1 ligand (PD-L1) (avelumab, atezolizumab, and durvalumab). As of May 2017, nivolumab and pembrolizumab were approved for the following indications: advanced melanoma, non-small cell lung cancer, Hodgkin's lymphoma, and bladder urothelial cancer. Pembolizumab was approved for additional indications: renal cell carcinoma, head and neck cancer, merkel cell carcinoma, and tumors of any organ with high microsatellite instability. Further idications for anti-PD-1 drugs alone, or in combination with immunotherapeutic and non-immunotherapeutic drugs, are under investigation in at least 135 clinical trials. ${ }^{1}$

Immunotherapy, as a drug class, boosts the body's natural defense against cancer. These drugs have adverse effects, collectively known as immunerelated adverse events, that represent immune effects on normal tissue that can result from misdirected stimulation of the immune system. Anti-PD-1 drugs are overall less toxic than standard chemotherapy, ${ }^{2-8}$ but immune-related adverse events have been reported in clinical trails. Organ specific immune-related adverse events including colitis, hepatitis, pneumonitis, 
and hypothyroidism as well as more general adverse events related to immune activation, including fatigue, diarrhea, and rash, have been common. ${ }^{2} 8$ Other adverse events potentially attributable to systemic inflammation, particularly musculoskeletal problems, have also been described in patients treated with anti-PD-1 drugs and may negatively impact quality of life, although their frequency is not known. ${ }^{9} 10$ A better understanding of the immune-related adverse events is necessary to determine the risk benefit for prescribing anti-PD-1 drugs to an increasing number of patients. ${ }^{1}$

We performed a systematic review and meta-analysis of immune-related adverse eventsof anti-PD-1 and anti-PD-L1 drugs. We included organ specific and other adverse eventspotentially related to inflammation and gathered data from both ClinicalTrials.gov and published literature. We made serveral hypotheses. First, that rates of organ specific immune-related adverse events including colitis, hepatitis, pneumonitis, hypothyroidism, and hypophysitis would be low overall but higher with anti-PD-1 drugs than with standard treatments.Second, that rates of general adverse events related to immune activation specifically fatigue, diarrhea, and rash would be higher than organ specific immune-related adverse events but would not be increased compared with standard therapies. Third, that adverse events consistent with musculoskeletal problems would be common, but had been inconsistently documented.

\section{Methods}

We conducted a literature search to identify randomized clinical trials comparing one anti-programmed cell death 1 (anti-PD-1) or anti-PD-1 ligand (anti-PD-L1) drug to a control drug in patients with cancer. We evaluated the rates of organ specific immune-related

\section{Box 1: PubMed search terms}

- ("nivolumab"[Supplementary Concept] OR “Nivolumab"[tiab] AND “Opdivo"[tiab] OR “MDX-1106" [tiab] OR “ONO-4538”[tiab] OR “BMS-936558”[tiab] OR “NIVO”[tiab] OR “pembrolizumab"[Supplementary Concept] OR “pembrolizumab" [tiab] OR “lambrolizumab”[tiab] OR "keytruda”[tiab] OR “MK-3475”[tiab] OR “SCH 900475"[tiab] OR “avelumab”[Supplementary Concept] OR “Avelumab”[tiab] OR “MSB0010718C"[tiab] OR “MPDL3280A"[Supplementary Concept] OR “MPDL3280A" [tiab] OR “atezolizumab” [tiab] OR “Tecentriq"[tiab] OR “RG7446”[tiab] OR “RO5541267"[tiab] OR “Durvalumab”[tiab] OR “MEDI4736”[tiab] OR “MEDI-4736"[tiab] OR checkpoint inhibitor*[tiab] OR “PD-1"[tiab] OR “PDL1”[tiab]) AND (Clinical Trial, Phase III[ptyp] OR “phase 3 clinical trial”[tiab] OR "phase III clinical trial"[tiab] OR "phase 3 trial”[tiab] OR "phase III trial”[tiab] OR "phase 3 clinical study" [tiab] OR "phase III clinical study"[tiab] OR "phase 3 study" [tiab] OR “phase III study"[tiab] OR "phase 3 randomized trial”[tiab] OR "phase III randomized trial"[tiab] OR Clinical Trial, Phase II[ptyp] OR "phase 2 clinical trial"[tiab] OR "phase II clinical trial”[tiab] OR "phase 2 trial”[tiab] OR "phase II trial”[tiab] OR “phase 2 clinical study"[tiab] OR “phase II clinical study" [tiab] OR "phase 2 randomized trial”[tiab] OR "phase II randomized trial"[tiab] OR "phase 2 study"[tiab] OR "phase II study"[tiab] OR "phase $2 / 3$ clinical trial"[tiab] OR "phase II/ III clinical trial"[tiab] OR “phase 2/3 trial”[tiab] OR "phase II/III trial"[tiab] OR "phase $2 / 3$ clinical study"[tiab] OR "phase II/ III clinical study" [tiab] OR “phase 2/3 study"[tiab] OR “phase II/III study"[tiab] OR “phase 2/3 randomized trial"[tiab] OR "phase II/III randomized trial"[tiab] OR Randomized Controlled Trial[ptyp] OR “randomized controlled trial”[tiab] OR “RCT”[tiab]) adverse events, general adverse events related to immune activation, and adverse events consistent with musculoskeletal problems and calculated the risks compared with control treatments. We performed the study in adherence with the PRISMA (Preferred Reporting Items for Systematic Reviews and MetaAnalysis) guidelines. ${ }^{11}$

\section{Data sources and searches}

We electronically searched five databases (Medline (PubMed), Embase, Cochrane Central Register of Controlled Trials, Web of Science, and Scopus) from the inception of all searched databases in August 2016 and updated the search in March 2017. For PubMed, Embase, and Cochrane, we used both controlled vocabulary and text words for synonymous terminology within titles and abstracts in the development of search strategies. Web of Science and Scopus were searched using only text word searching of titles and abstracts. The search strategy contained two concepts that were linked together with the AND operator: ${ }^{1}$ nivolumab, pembrolizumab, ipilimumab, avelumab, tremelimumab, atezolizumab, durvalumab, checkpoint inhibitors; and phase II clinical trials, phase III clinical trials, randomized controlled trials. ${ }^{2}$ Box 1 shows the complete list of search terms. We combined the search results in a bibliographic management tool (EndNote) and used the Bramer method to eliminate duplicates. ${ }^{12}$

\section{Study selection}

We included studies that examined a cancer and reported results of a randomized study of an antiPD-1 or anti-PD-L1 monoclonal antibody. We excluded reviews, commentaries, studies published only in abstract form, quality of life studies, cost effectiveness analyses, and those in which the effect of the drug could not be ascertained, such as when the control was a different dose of the same drug or another checkpoint inhibitor. The study selection was performed in two stages. Two authors (SB and ZW) screened all titles and abstracts for full text review. Three authors (SB, DK, and ZW) reviewed and discussed the full text articles. Disagreements were resolved by concensus. All included studies represented unique trials.

\section{Data extraction and quality assessment}

Data from each study was extracted by two of three authors (SB, DK, and NK). Disagreements were resolved by concensus involving all three. We extracted patient characterisitics (sex, performance status, and age), the sizes of intervention and control groups, median treatment time, and median follow-up from each study. Two of three authors (DK, AY, and SB) independently assessed the quality of all articles included in the review using the Cochrane Risk of Bias Tool and used a weighted Cohen's kappa coefficient $(\kappa)$ to measure agreement. ${ }^{13}$ To optimize relevance to immune-related adverse events we evaluated the risk of bias with regard to adverse event outcomes, not the efficacy outcomes the individual studies were primarily designed to assess. Differences were resolved by consensus. 


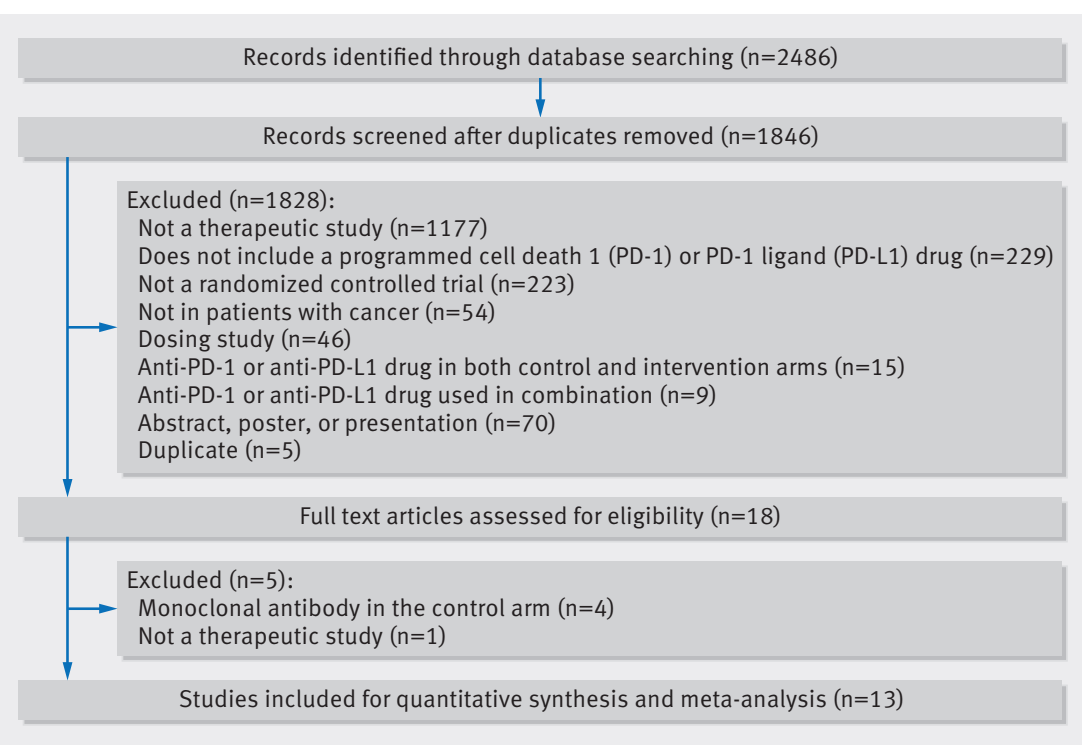

Fig 1 | Study flow diagram

Our primary outcome was the incidence of commonly described organ specific immune-related adverse events (colitis, hepatitis, pnemonitis, hypophysitis or hypopituitarism, and hypothyroidism) and general adverse events related to immune activation (fatigue, diarrhea, and rash). Our secondary outcome was the incidence of adverse events consistent with musculoskeletal problems (arthritis, arthralgia, back pain, musculoskeletal pain, and myalgia). We first searched for adverse event data on ClinicalTrials.gov on 28 March 2017. For studies for which full adverse event information was not on ClinicalTrials.gov, we used information from the publication and directly contacted study authors or pharmaceutical sponsors for additional information. We recorded data on adverse events reported as either serious or other on ClinicalTrials.gov. For data extracted from published reports, we used the Common Terminology of Clinical Adverse Events (CTCAE) categorization to identify grades 3-5 as serious and CTCAE grades 1-2 as other.
For studies with information available from both sources, we prioritized data from ClinicalTrials.gov over adverse event data from the publications, because it was more complete. If the study did not report a specific adverse event, we assumed that the event did not occur. Data from different dosing arms within the same study were extracted and reported separately.

\section{Data synthesis and analysis}

We calculated overall event rates by dividing the total number of patients across trials with a given adverse event by the total number at risk. We examined the number of events for each immune-related adverse event of interest to determine whether meta-analysis was feasible. For each included study, we calculated odds ratios and 95\% confidence intervals for event rates in the intervention arm compared with control based on the reported number of events and sample size. We used the $\mathrm{I}^{2}$ index and the Cochran Q statistic to examine heterogeneity across trials for each outcome. If significant heterogeneity was not present $(\mathrm{P}>0.1)$, pooled odds ratio and 95\% confidence interval were estimated with a fixed effects model using the inverse variance method. A random effects model using the inverse variance method was used to calculate pooled odds ratio and 95\% confidence interval if significant heterogeneity was present $(\mathrm{P} \leq 0.1)$. Studies were weighted based on theinverse of the variance of the effect estimate. If a study included more than one intervention arm (eg, Herbst and Ribas reported $2 \mathrm{mg} / \mathrm{kg}$ and 10 $\mathrm{mg} / \mathrm{kg}$ arms for pembrolizaumab), ${ }^{14} 15$ we separately compared each intervention arm with the control arm. We conducted subgroup analyses to examine studies by control group treatment (chemotherapy $v$ targeted treatment). We used funnel plots to asses publication bias. All statistical analyses were conducted using Review Manager 5.3 (Copenhagen, Denmark).

\section{Patient involvement}

No patients were involved in setting the research question or the outcome measures, nor were they involved in

\begin{tabular}{|c|c|c|c|c|c|c|c|c|}
\hline Study & Year & Randomization & $\begin{array}{l}\text { Allocation } \\
\text { concealment }\end{array}$ & $\begin{array}{l}\text { Blinding of } \\
\text { participants } \\
\text { and staff }\end{array}$ & $\begin{array}{l}\text { Blinding of } \\
\text { outcome } \\
\text { assessors* }\end{array}$ & $\begin{array}{l}\text { Incomplete } \\
\text { outcome datat }\end{array}$ & $\begin{array}{l}\text { Selective } \\
\text { outcome } \\
\text { reportingt }\end{array}$ & $\begin{array}{l}\text { Other } \\
\text { sources } \\
\text { of bias }\end{array}$ \\
\hline Bellmunt & 2017 & Low & Unclear & High & High & High & High & Low \\
\hline Borghaei & 2015 & Low & Low & High & High & High & High & Low \\
\hline Brahmer & 2015 & Low & Low & High & High & High & High & Low \\
\hline Fehrenbacher & 2016 & Low & Low & High & High & High & High & Low \\
\hline Ferris & 2016 & Low & Low & High & High & High & High & Low \\
\hline Herbst & 2016 & Low & Low & High & High & High & High & Low \\
\hline Langer & 2016 & Low & Low & High & High & High & High & Low \\
\hline Motzer & 2015 & Low & Low & High & High & High & High & Low \\
\hline Reck & 2016 & Low & Unclear & High & High & High & High & Low \\
\hline Ribas & 2015 & Low & Low & High & High & High & High & Low \\
\hline Rittmeyer & 2017 & Low & Low & High & High & High & High & Low \\
\hline Robert & 2015 & Low & Low & Low & Low & High & High & Low \\
\hline Weber & 2015 & Low & Low & High & High & High & High & Low \\
\hline Kappa & NA & 1.00 & 1.00 & 0.629 & 0.629 & 1.00 & 1.00 & 1.00 \\
\hline
\end{tabular}

$\mathrm{NA}=$ not applicable.

*Based on clinician blinding since clinicians assessed adverse events for all studies.

tApplies to adverse events. 


\begin{tabular}{|c|c|c|c|c|c|c|c|c|c|c|c|}
\hline \multirow[b]{2}{*}{ Drug } & \multirow[b]{2}{*}{ No } & \multicolumn{2}{|l|}{ Colitis } & \multicolumn{2}{|c|}{ Hepatitis } & \multicolumn{2}{|c|}{ Pneumonitis } & \multicolumn{2}{|c|}{ Hypothyroidism } & \multicolumn{2}{|c|}{ Hypophysitis } \\
\hline & & $\overline{A l l *}$ & Serioust & All & Serious & All & Serious & All & Serious & All & Serious \\
\hline Atezolizumab & 751 & $\begin{array}{l}0.5(0.2 \\
\text { to } 1.4)\end{array}$ & $\begin{array}{l}0.1(0.0 \\
\text { to } 0.7)\end{array}$ & $\begin{array}{l}0.4(0.0 \\
\text { to } 1.2)\end{array}$ & $\begin{array}{l}0.3(0.0 \\
\text { to } 1.0)\end{array}$ & $\begin{array}{l}0.8(0.3 \\
\text { to } 1.7)\end{array}$ & $\begin{array}{l}0.5(0.2 \\
\text { to } 1.4)\end{array}$ & $\begin{array}{l}1.1(0.5 \\
\text { to } 2.1)\end{array}$ & $\begin{array}{l}0.1(0.0 \\
\text { to } 0.7)\end{array}$ & $\begin{array}{l}0.0(0.0 \\
\text { to } 0.4)\end{array}$ & $\begin{array}{l}0.0(0.0 \\
\text { to } 0.4)\end{array}$ \\
\hline Nivolumab & 1534 & $\begin{array}{l}0.3(0.1 \\
\text { to } 0.8)\end{array}$ & $\begin{array}{l}0.3(0.1 \\
\text { to } 0.8)\end{array}$ & $\begin{array}{l}0.0(0.0 \\
\text { to } 0.2)\end{array}$ & $\begin{array}{l}0.0(0.0 \\
\text { to } 0.2)\end{array}$ & $\begin{array}{l}2.2(1.5 \\
\text { to } 3.1)\end{array}$ & $\begin{array}{l}1.1(0.7 \\
\text { to } 1.8)\end{array}$ & $\begin{array}{l}5.9(4.7 \\
\text { to } 7.2)\end{array}$ & $\begin{array}{l}0.2(0.0 \\
\text { to } 0.6)\end{array}$ & $\begin{array}{l}0.3(0.1 \\
\text { to } 0.8)\end{array}$ & $\begin{array}{l}0.2(0.0 \\
\text { to } 0.6)\end{array}$ \\
\hline Pembrolizumab & $1518 \ddagger$ & $\begin{array}{l}1.1(0.6 \\
\text { to } 1.7)\end{array}$ & $\begin{array}{l}0.8(0.4 \\
\text { to } 1.4)\end{array}$ & $\begin{array}{l}0.2(0.0 \\
\text { to } 0.6)\end{array}$ & $\begin{array}{l}0.2(0.0 \\
\text { to } 0.6)\end{array}$ & $\begin{array}{l}3.1(2.2 \\
\text { to } 4.0)\end{array}$ & $\begin{array}{l}2.2(1.5 \\
\text { to } 3.0)\end{array}$ & $\begin{array}{l}7.6(6.4 \\
\text { to } 9.1)\end{array}$ & $\begin{array}{l}0.1(0.0 \\
\text { to } 0.5)\end{array}$ & $\begin{array}{l}0.4(0.2 \\
\text { to } 0.9)\end{array}$ & $\begin{array}{l}0.4(0.2 \\
\text { to } 0.9)\end{array}$ \\
\hline Total & 3803 & $\begin{array}{l}0.7(0.4 \\
\text { to } 1.0)\end{array}$ & $\begin{array}{l}0.5(0.3 \\
\text { to } 0.8)\end{array}$ & $\begin{array}{l}0.2(0.1 \\
\text { to } 0.3)\end{array}$ & $\begin{array}{l}0.1(0.0 \\
\text { to } 0.3)\end{array}$ & $\begin{array}{l}2.2(1.8 \\
\text { to } 2.7)\end{array}$ & $\begin{array}{l}1.4(1.1 \\
\text { to } 1.9)\end{array}$ & $\begin{array}{l}5.6(4.9 \\
\text { to } 6.4)\end{array}$ & $\begin{array}{l}0.2(0.1 \\
\text { to } 0.3)\end{array}$ & $\begin{array}{l}0.3(0.1 \\
\text { to } 0.5)\end{array}$ & $\begin{array}{l}0.2(0.1 \\
\text { to } 0.5)\end{array}$ \\
\hline
\end{tabular}

*Includes both serious and other adverse events if data were extracted from ClinicalTrials.gov; includes all Common Terminology of Clinical Adverse Events (CTCAE) grades if data were extracted from the publication.

tRepresents serious adverse events if data were extracted from ClinicalTrials.gov; represents CTCAE grades 3, 4, or 5 if data were extracted from the publication.

¥Includes both the $2 \mathrm{mg} / \mathrm{kg}$ and $10 \mathrm{mg} / \mathrm{kg}$ dosing arms of Herbst, 2016 and Ribas, 2015.

developing plans for design or implementation of the study. No patients were asked to advise on interpretation or writing up of results. There are no plans to disseminate the results of the research to study participants or the relevant patient community. It was not evaluated whether the studies included in the review had any patient involvement.

\section{Results}

Figure 1 shows that our search identified 2486 records; 18 underwent full text review and 13 were included for quantitiative synthesis and meta- analysis. ${ }^{14-26}$ Included articles were published (online) between November 2014 and February 2017. Funnel plots showed no evidence of publication bias (web appendix 1).

\section{Study characteristics}

All studies were international multi center studies funded by the pharmaceutical industry, with intervention group sample sizes ranging from 59 to 609 patients. Seven were completed in patients with metastatic non-small cell lung cancer, ${ }^{14-17} 2123$ 2426 three in melanoma, ${ }^{15} 1920$ and one each in renal

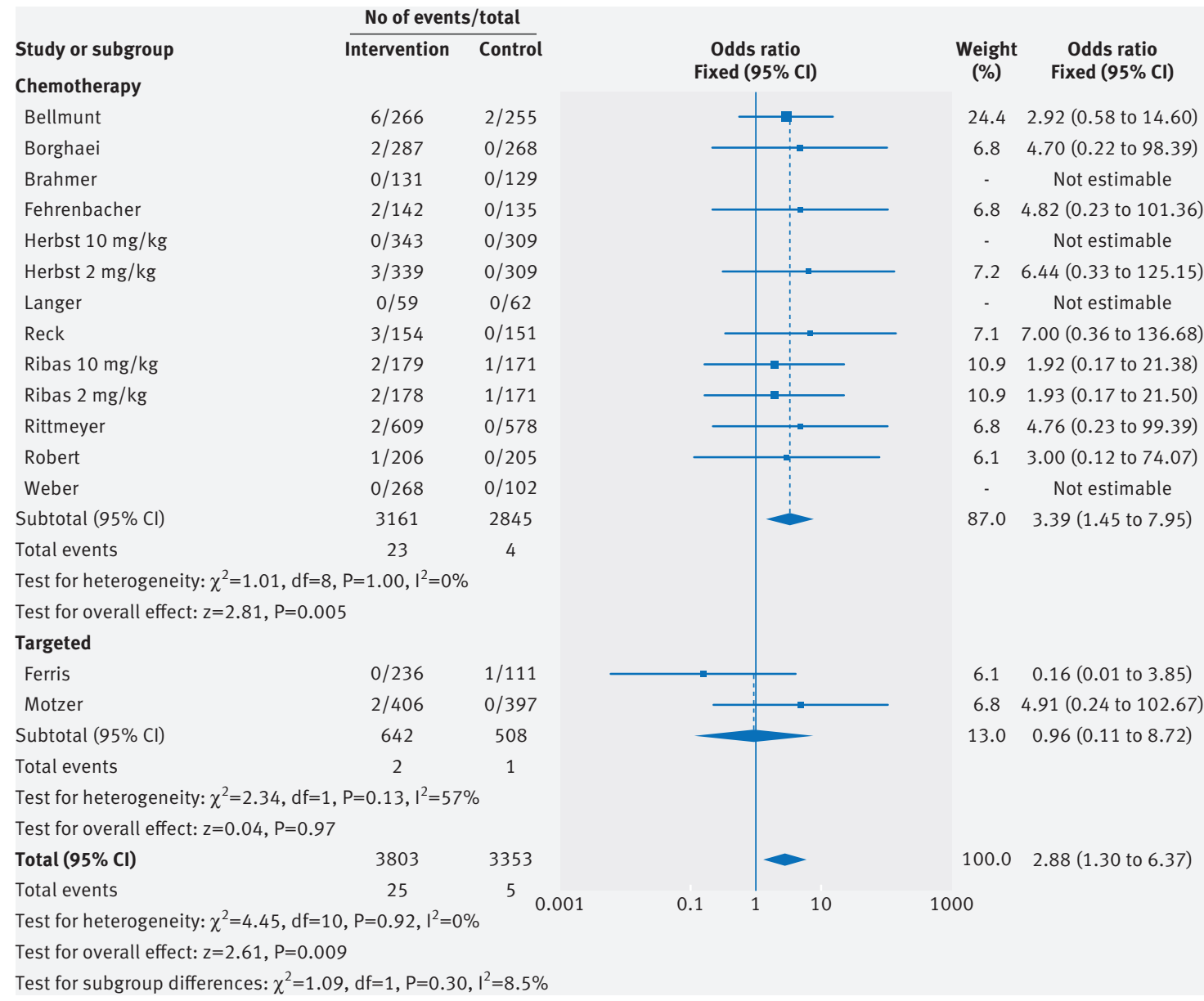

Fig 2 | Forest plot of colitis in patients treated with anti-PD-1 drugs versus control 


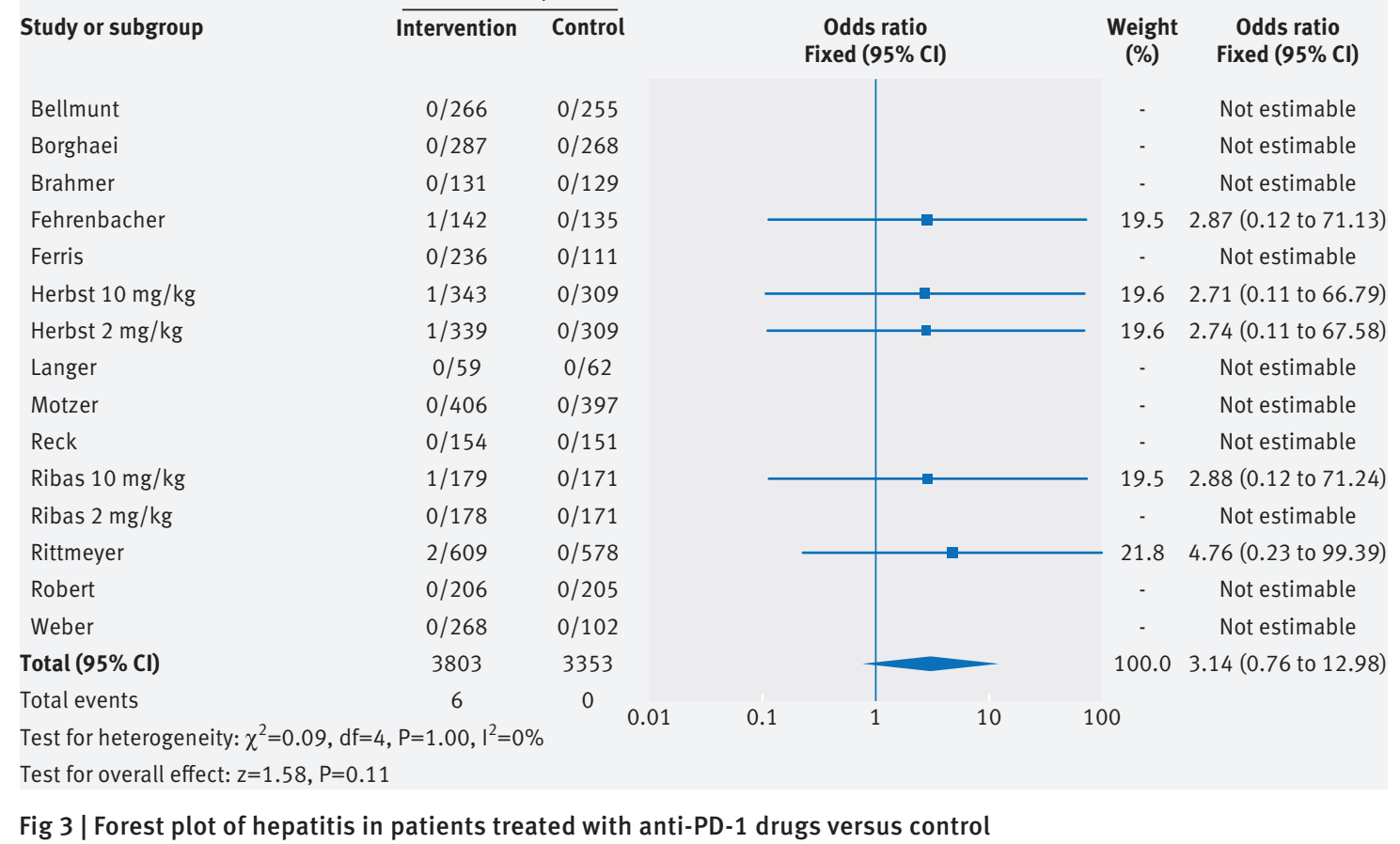

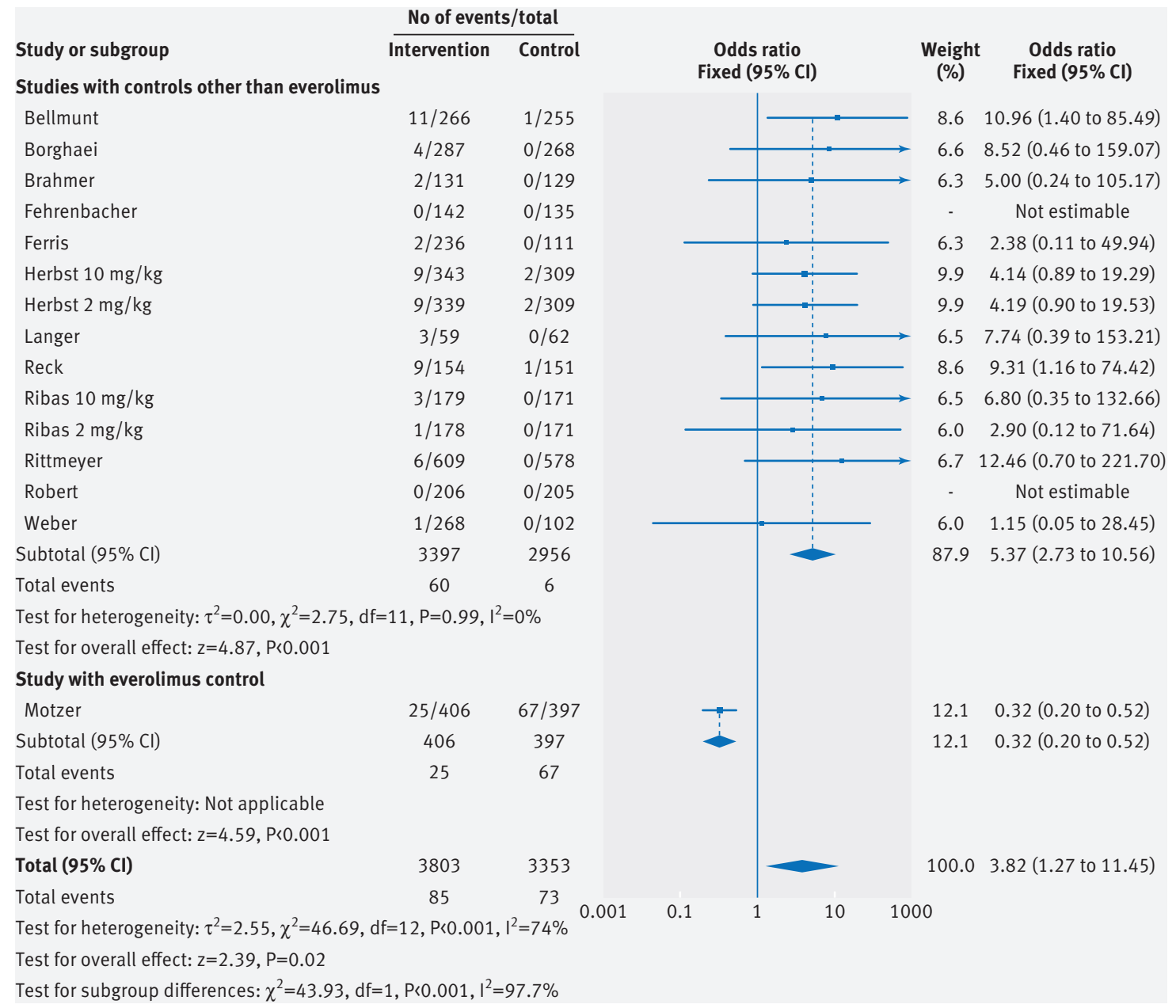

Fig 4 | Forest plot of pneumonitis in patients treated with anti-PD-1 drugs versus control 


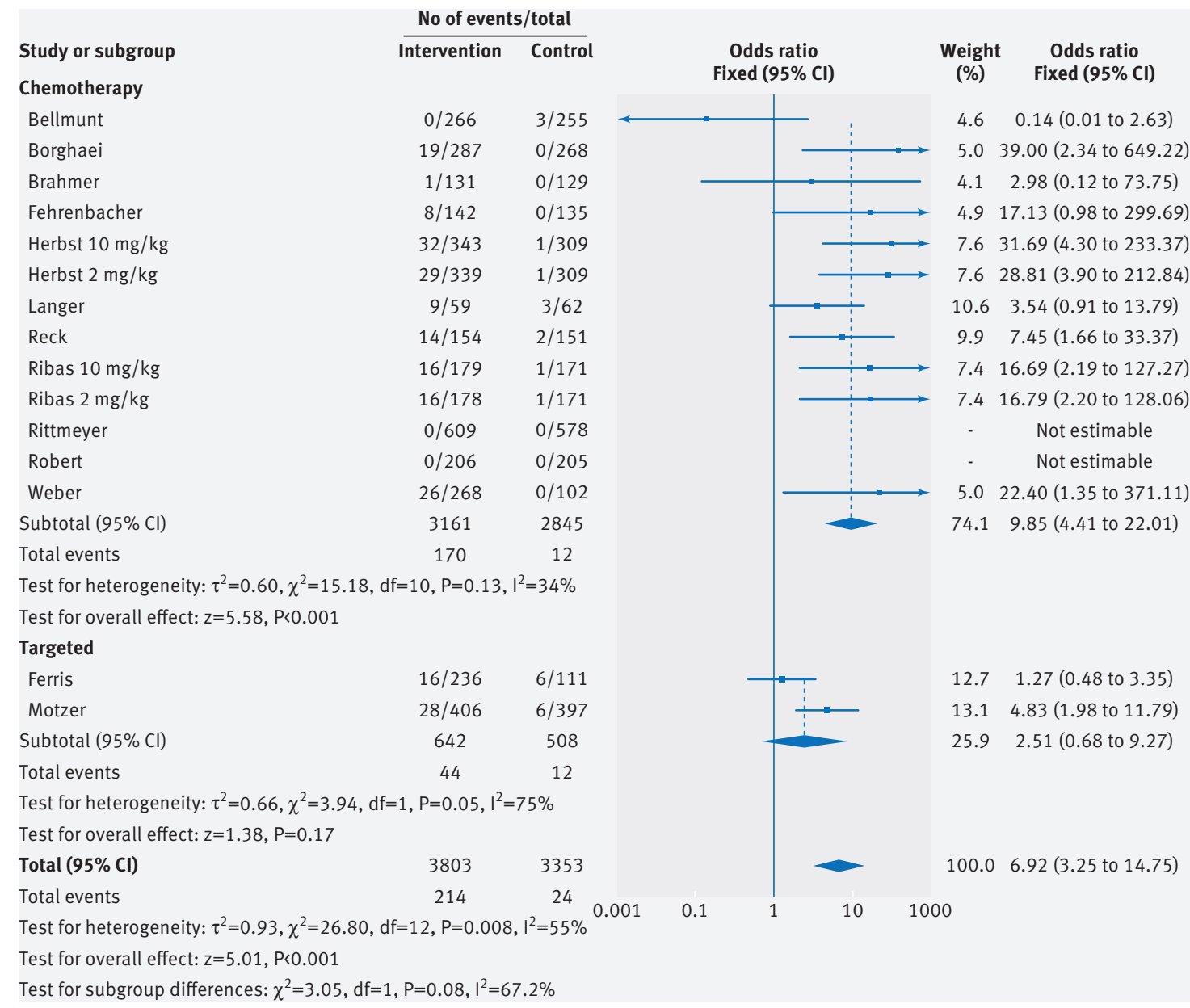

Fig 5 | Forest plot of hypothyroidism in patients treated with anti-PD-1 drugs versus control

cell carcinoma, $^{18}$ bladder cell carcinoma $^{25}$ and head and neck squamous cell carcinoma. ${ }^{22}$ Patients in the intervention arm received nivolumab in six studies, ${ }^{16-20} 22$ pembrolizumab in five studies, ${ }^{14} 15$ 23-25 and atezolizumab in two studies. ${ }^{2126}$ One trial evaluated the combination of pembrolizumab with chemotherapy (carboplatin and pemetrexed) compared with chemotherapy (carboplatin and pemetrexed) alone. ${ }^{23}$ In two studies evaluating pembrolizumab, two different doses $(2 \mathrm{mg} / \mathrm{kg}$ and $10 \mathrm{mg} / \mathrm{kg})$ were compared with each other, in addition to a standard control. ${ }^{14} 15$ The control arm was one chemotherapy drug in six studies, ${ }^{14} 1617192126$ two chemotherapy drugs in one study, ${ }^{23}$ a small molecule inhibitor in one study, ${ }^{18}$ and the investigators' choice in four studies. ${ }^{15}$ 202225 For all studies, the primary endpoint was survival, with adverse events reported as secondary outcomes. All studies continued treatment until the disease progressed or severe adverse events occured. The median treatment time in the investigational arm was 3.9 months (range 3 to 8 months) and the median duration of follow-up across studies was 13.1 months (range 5 to 25 months). As of 27 March 2017, all studies were registered on ClinicalTrials.gov and adverse event data was available on ClinicalTrials.gov for eight studies.

\section{Quality of included studies}

Table 1 shows that there was high inter-rater agreement for risk of bias assessments ( $\kappa$ between 0.629 and 1.00 across domains). ${ }^{13}$ All studies but one were open label with primary outcome of overall survival. Reports of adverse event rates in these open label studies were unmasked because adverse event reporting was performed by the clinicians directly caring for patients. Further, because included studies were not designed primarily to assess adverse events, collection of adverse event information was poorly described, and we deemed all studies at high risk of bias with regard to incomplete outcome data and selective outcome reporting.

\section{Organ specific immune-related adverse events}

A total of 6676 patients were evaluated across the 13 studies with 3803 in the investigational arm (nivolumab 1534, pembrolizumab 1459, and azetolizmumab 751) and 2873 in control arms (chemotherapy including cetuximab 2476, or a biological agent 397). All studies reported organ specific immune-related adverse events of interest. Looking at any grade organ specific immune-related adverse events, among the 3803 total patients exposed to anti-PD-1 drugs 214 (5.6\%) had hypothyroidism, 85 (2.2\%) had pneumonitis, 25 


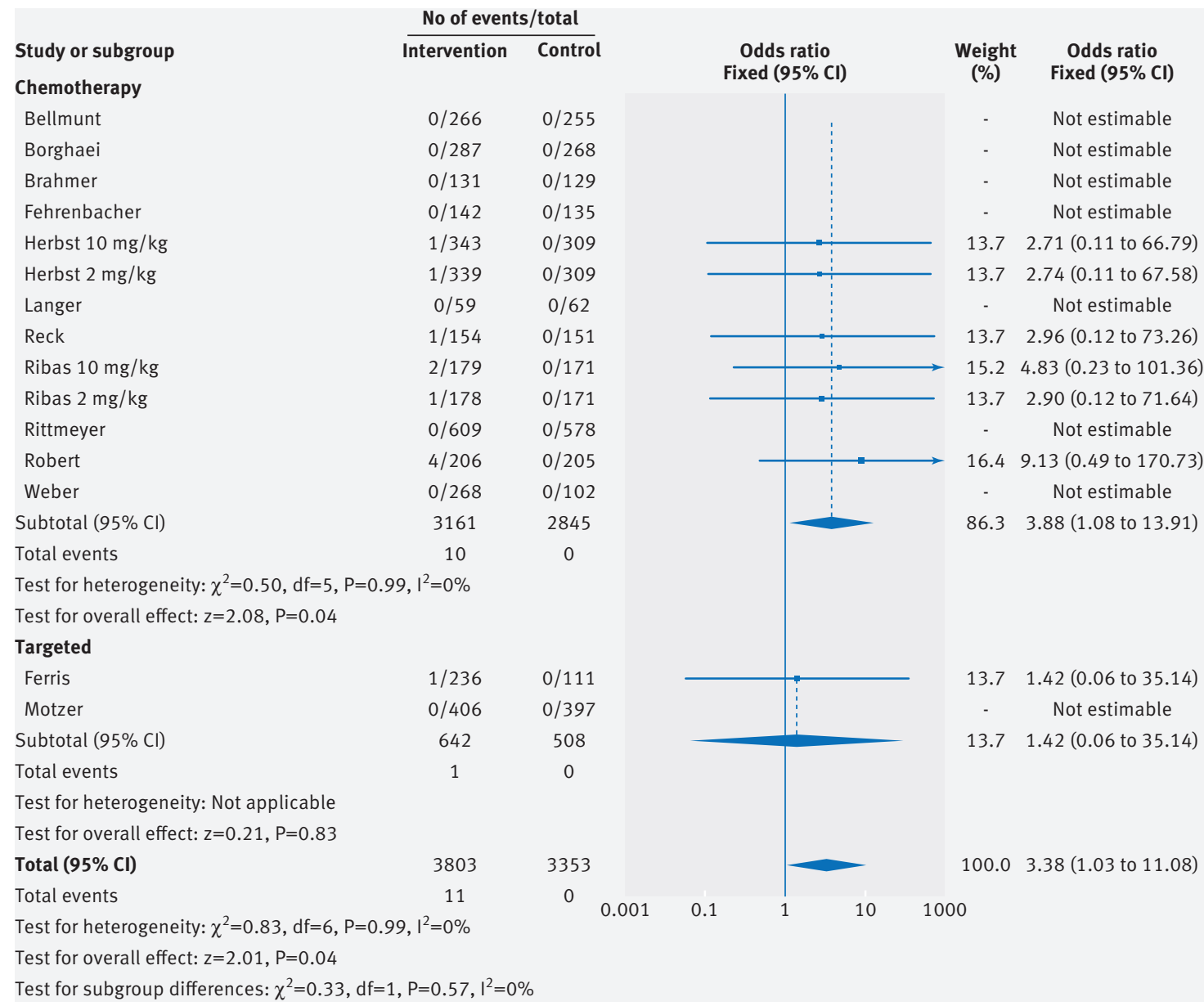

Fig 6 | Forest plot of hypophysitis in patients treated with anti-PD-1 drugs versus control

$(0.7 \%)$ had colitis, $6(0.2 \%)$ had hepatitis, and 11 $(0.3 \%)$ had hypophysitis. The most common serious immune-related adverse events was pneumonitis which occurred in $54(1.4 \%)$ patients, while serious colitis, hypothyroidism, hepatitis, and hypophysitis occurred in $18(0.5 \%), 6(0.2 \%), 5(0.1 \%)$, and 9 $(0.2 \%)$ patients respectively. Table 2 shows the rates of organ specific serious immune-related adverse events by drug.

Figure 2 shows that in the meta-analysis, compared with patients treated in control arms, those treated with anti-PD-1 drugs were at higher risk for colitis (odds ratio 2.88, 95\% confidence interval 1.30 to 6.37, $\mathrm{P}=0.009$ ). Figure 3 shows that they were not at increased risk of hepatitis $(3.14,0.76$ to 12.98 , $\mathrm{P}=0.11$ ), though events were rare. Figure 4 shows that pneumonitis, excluding the study in which the control treatment was everolimus, a drug known to causes pneumonitis, the risk of pneumonitis with anti-PD-1 drugs was also higher than the control $(5.37,2.73$ to 10.56, $\mathrm{P}<0.001)$. The risk was lower with anti-PD-1 drugs compared with everolimus; the overall pooled estimate may not be meaningful. Figure 5 shows that patients treated with anti-PD-1 drugs were at a higher risk for any grade hypothyroidism $(6.92,3.25$ to $14.75, \mathrm{P}<0.001)$. Figure 6 shows that patients treated with anti-PD-1 drugs were at higher risk for any grade hypophysitis (3.38, 1.03 to $11.08, \mathrm{P}=0.04$ ).

\section{General adverse events related to immune activation}

All studies reported rates of fatigue and diarrhea and 12 reported rash. In the intervention arms of these studies, rates of fatigue, diarrhea, and rash were seen in 1208 (32\%), $705(19 \%)$, and $393(10 \%)$ patients respectively. Figure 7 shows that patients treated with anti-PD-1 drugs were more likely to experience rash (odds ratio 2.34, 95\% confidence interval 1.40 to $3.91, \mathrm{P}=0.001)$. Figure 8 and figure 9 show that patients were less likely to report fatigue $(0.84,0.65$ to $1.09, \mathrm{P}=0.19)$ or diarrhea $(0.78,0.57$ to $1.05, \mathrm{P}=0.10)$ compared with patients in the control arms.

\section{Adverse events consistent with musculoskeletal problems}

Table 3 shows that reporting adverse events consistent with musculoskeletal problems, including arthritis, arthralgia, back pain, musculoskeletal pain, and myalgia, varied across studies. Three studies included no mention of musculoskeletal problems. On ClinicalTrials.gov, among the eight studies for which data was provided, arthralgia, back pain, 


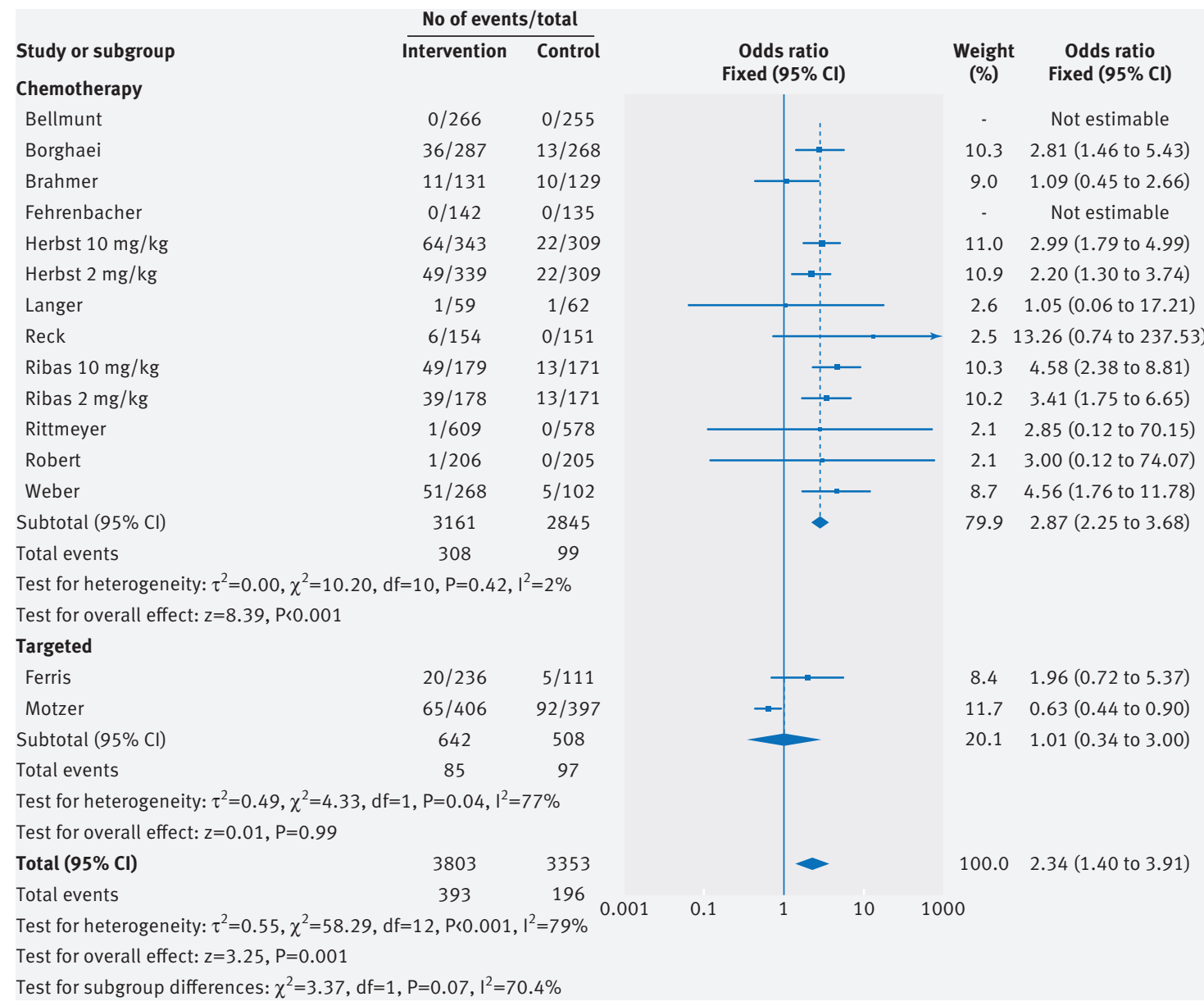

Fig 7 | Forest plot of rash in patients treated with anti-PD-1 drugs versus control

musculoskeletal pain, and myalgia were reported in all studies while arthritis was reported in two. When reported, rates of musculoskeletal problems varied across studies in intervention groups, ranging from $10 \%$ to $26 \%$ for arthralgia, $6 \%$ to $22 \%$ for back pain, $6 \%$ to $14 \%$ for musculoskeletal pain, and $2 \%$ to $12 \%$ for myalgia. Single cases of arthritis were reported in two studies at a rate of below $1 \%$ in each. Across control groups, rates of musculoskeletal compaints ranged from $9 \%$ to $18 \%$ for arthralgia, $2 \%$ to $16 \%$ for back pain, $4 \%$ to $6 \%$ for musculoskeletal pain, and $4 \%$ to $16 \%$ for myalgia, when reported. Lack of reporting adverse events consistent with musculoskeletal problems precluded data pooling, so we did not perform a meta-analysis for these outcomes.

\section{Discussion}

We completed a systematic review of immune-related adverse events of anti-programmed cell death 1 (antiPD-1) or anti-PD-1 ligand (PD-L1) monoclonal antibodies versus a standard treatment to further our understanding of the safety of this emerging class of drugs. We used data from 13 randomized trials that included over 3800 patients treated with checkpoint inhibitors and extracted data from ClinicalTrials.gov, when possible, to supplement the published evidence base.
Our study is notable for our inclusion of adverse event information from ClinicalTrials.gov and our focus on anti-PD-1 drugs. A recent meta-analysis evaluated the risk of immune-related adverse events in patients treated with any checkpoint inhibitor (including ipilimumab). ${ }^{27}$ Unlike the prior study, we found an increased risk of pneumonitis with antiPD-1 drugs compared with control treatments other than everolimus, though our findings regarding risk of colitis were similar. Any differences in findings are likely owing to our access to more complete adverse event data through ClinicalTrials.gov and our inclusion of more studies of anti-PD-1 drugs. In addition, by using data from ClinicalTrials.gov we were able to evaluate adverse events consistent with musculoskeletal problems, which are likely to be important to patients.

Our findings have important implications for clinicians across multiple specialties. As use of antiPD-1 drugs grows, non-oncology specialists will be increasingly called upon to manage the rare but clinically important organ specific immune-related adverse events and the more prevalent general adverse events related to immune activation. ${ }^{28} 29$ In addition to severe adverse events such as pneumonitis and colitis, our study documents musculoskeletal problems that 


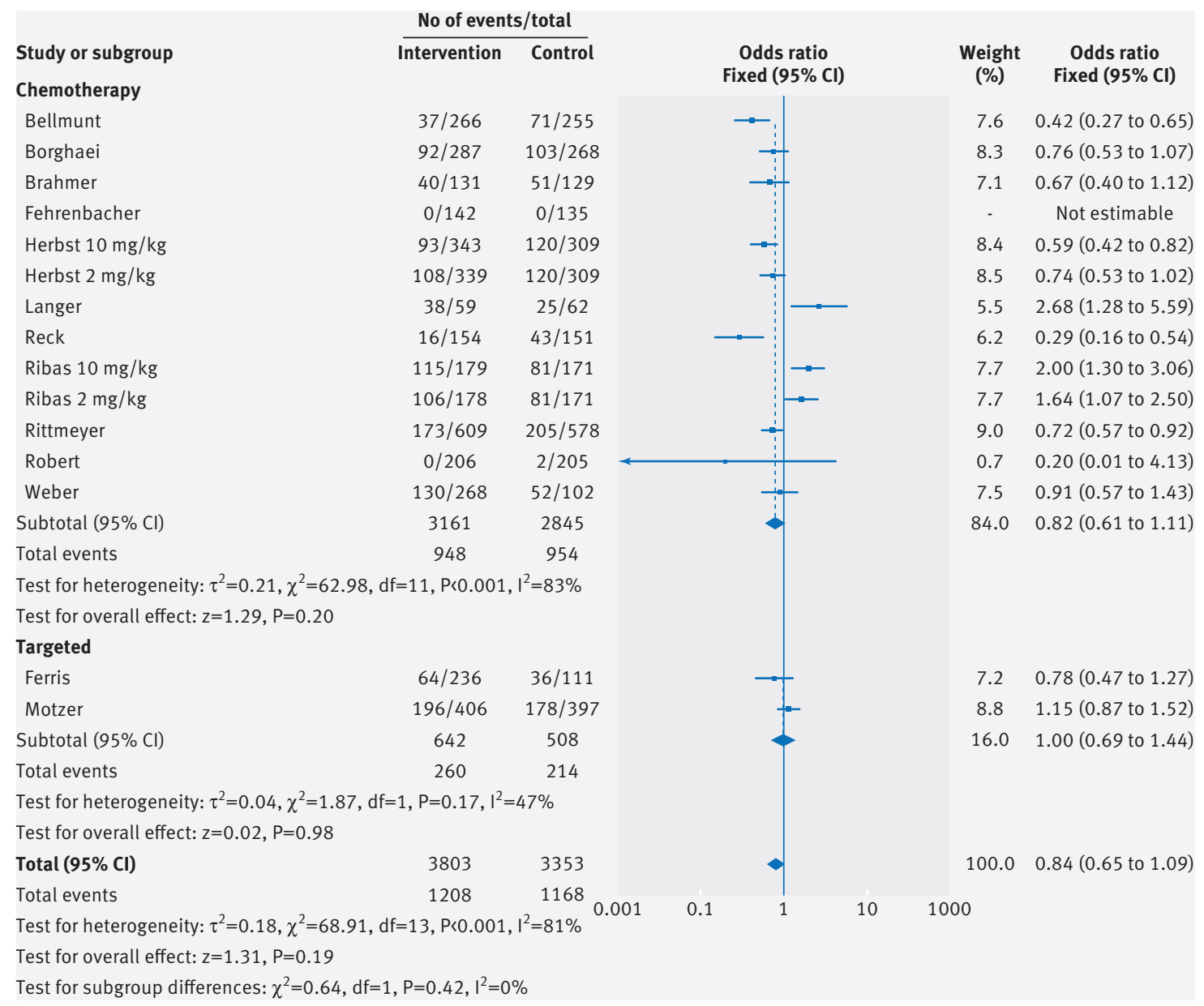

Fig 8 | Forest plot of fatigue in patients treated with anti-PD-1 drugs versus control

will require management by primary care physicians and rheumatologists. ${ }^{9} 10$ These problems are not surprising given that many autoimmune diseases have musculoskeletal manifestations. ${ }^{30}$ Inflammatory arthritis from checkpoint inhibitors has already been recognized in the rheumatology community; these adverse events are likely to grow in prevalence over time. ${ }^{10}$ 31-34 Currently, many oncology patients are treated primarily by their oncologists and may lose connections to other physicians. ${ }^{35} 36$ This care model may poorly serve patients treated with checkpoint inhibitors, whose cancers may remain under control but in whom a variety of adverse events may threaten health and quality of life. Multidisciplinary clinical teams may better serve these patients' long term needs, though optimal clinical and care delivery approaches for the early detection and proper management of immune-related adverse events are evolving and will require further investigation. ${ }^{37} 38$

Anti-PD-1 drugs can achieve long term tumor control through prolonged immune activation, so immunerelated adverse events requiring management may persist, progress, or even emerge over time. ${ }^{29}$ Studies included in our analysis had a median follow-up time of 13.1 months (range 5-25 months), which may be inadequate for capturing the full spectrum of longer term immune-related adverse events. With a focus on acute or short term adverse events captured in clinical trials, our study may have underestimated the prevalence of late developing or persistent immunerelated adverse events. Better understanding of the long term adverse events of monoclonal antibodies will be critical to efforts to optimize delivery of care. Phase IV studies are often recommended to enhance understanding of long term adverse events of new approved drugs, although they are seldom performed and are time consuming. ${ }^{39}$ Given the rapid anticipated growth in the number of patients treated with antiPD-1 drugs, institutional cohort studies could provide more immediate insights into immune-related adverse events with an emphasis on not just short term, but also long term, adverse events. In addition, investigators should publish updated adverse event information as well as cancer outcomes as they report longer follow-up from earlier studies of checkpoint inhibitors. Only a small amount of this type of data are publicly available.

We found that despite high rates of adverse events consistent with muscoskeletal problems, reporting of these adverse events was inconsistent and incomplete across trials. Accessing adverse events data on ClinicalTrials.gov enabled us to include information 


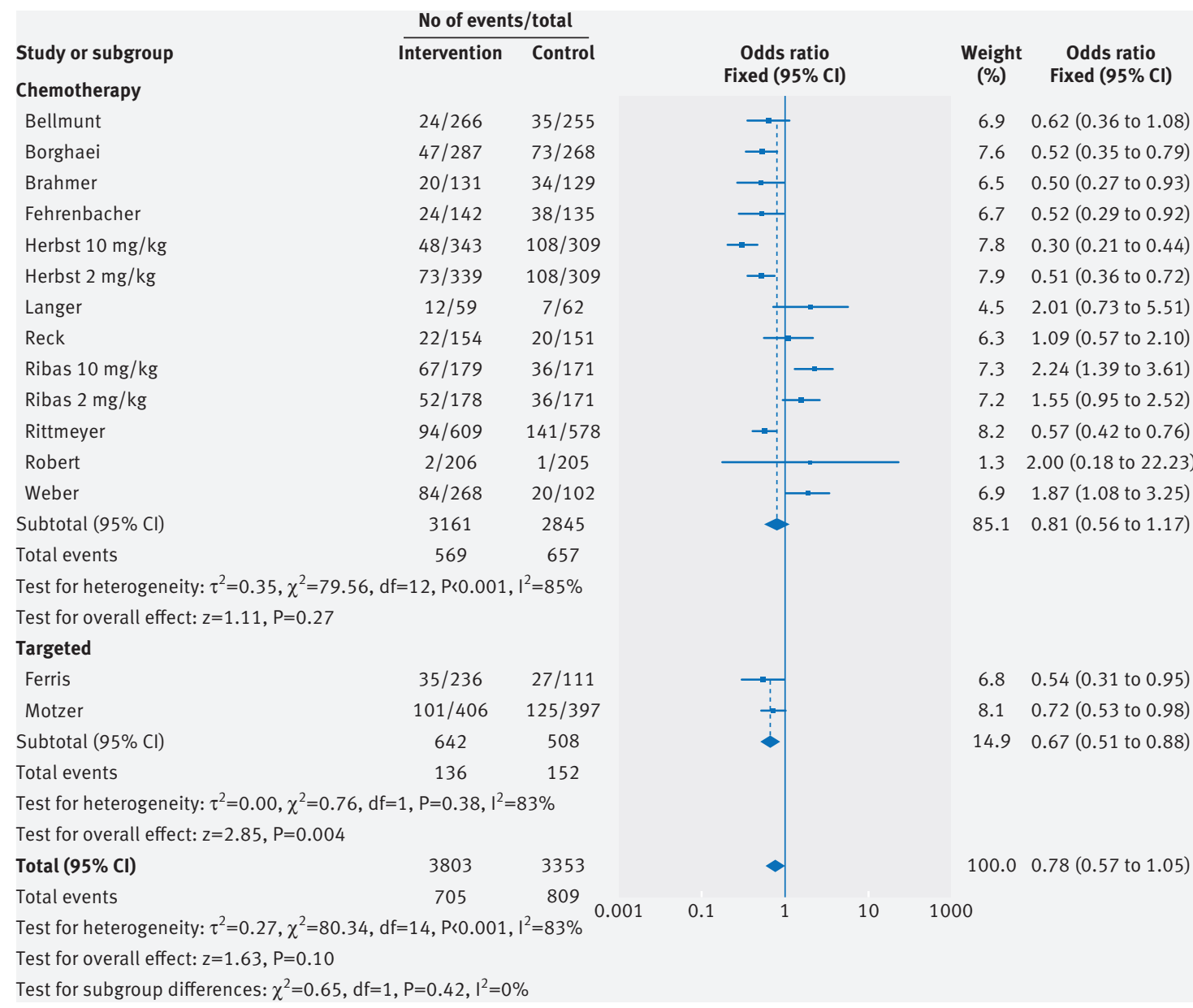

Fig 9 | Forest plot of diarrhea in patients treated with anti-PD-1 drugs versus control

that did not appear in publications, however, we remained constrained by the recording methods for adverse events in clinical trials. Adverse events in clinical trials are reported using Common Terminology of Clinical Adverse Events (CTCAE), which prompts investigators to note the presence or absence of a symptom or an abnormal laboratory value and grade it based upon its clinical significance. The process is highly subjective and relies on investigator recognition and identification of syndromes of interest, thus investigators may be more likely to classify patient complaints or findings as diagnoses of which they have high suspicion. In the case of anti-PD-1 drugs, investigators are aware of well described immunerelated adverse events such as colitis, hepatitis, pneumonitis, or hypothyroidism and are likely to report them accurately. Investogators may be less aware of other potentially relevant adverse events such as musculoskeletal problems and may therefore inaccurately diagnose and record them. Emerging case reports and case series have described rheumatologic and musculoskeletal syndromes related to systemic inflammation that have been seen in clinical practice but not described in primary publications of trial results. ${ }^{91040}$ Similar attention has been turned to less frequent, but important adverse events impacting the neurologic, cardiac, and ocular systems. ${ }^{41-44}$ As these receive more attention, problems such as arthritis, arthralgia, and myalgia may become more accurately reported in future studies.

\section{Weaknesses of this study}

Our study has important limitations. A major challenge of this review was the overlap in CTCAE definitions which prevents understanding the true rates of specific adverse events. For example, immune-related hepatitis could be captured as hepatitis or as an abnormal laboratory value (elevated aspartate transaminase and alanine transaminase) and immune-mediated colitis could be categorized as colitis or diarrhea. This could lead to potential uncertainty regarding the quality of the data, which will need to be addressed moving forward for studies of immunologic drugs. Further, a limitation of this analysis is that we assumed that the non-reporting of adverse event data was the result of either no events or non-measurement of the outcome. If a selective non-reporting mechanism were present, such that the adverse event data was measured but not reported based on the results, then there is the possibility that we may have overestimated the drugs' safety. ${ }^{45}$ In addition, while a strength of our study is our use of 


\begin{tabular}{|c|c|c|c|c|c|c|c|c|c|c|c|c|c|}
\hline \multirow[b]{2}{*}{ Author } & \multirow[b]{2}{*}{ Year } & \multirow[b]{2}{*}{ Drug } & \multirow[b]{2}{*}{ Intervention } & \multicolumn{2}{|l|}{ Arthritis } & \multicolumn{2}{|l|}{ Arthralgia } & \multicolumn{2}{|l|}{ Back pain } & \multicolumn{2}{|c|}{$\begin{array}{l}\text { Musculoskeletal } \\
\text { pain }\end{array}$} & \multicolumn{2}{|l|}{ Myalgia } \\
\hline & & & & $\overline{\text { All* }}$ & Serioust & All & Serious & All & Serious & All & Serious & All & Serious \\
\hline Bellmunt & $2017 \ddagger$ & Pembrolizumab & 266 & $\begin{array}{l}0(0.0 \\
\text { to } 1.1)\end{array}$ & $\begin{array}{l}0(0.0 \\
\text { to } 1.1)\end{array}$ & $\begin{array}{l}0(0.0 \\
\text { to } 1.1)\end{array}$ & $\begin{array}{l}0(0.0 \\
\text { to } 1.1)\end{array}$ & $\begin{array}{l}0(0.0 \\
\text { to } 1.1)\end{array}$ & $\begin{array}{l}0(0.0 \\
\text { to } 1.1)\end{array}$ & $\begin{array}{l}0(0.0 \\
\text { to } 1.1)\end{array}$ & $\begin{array}{l}0(0.0 \\
\text { to } 1.1)\end{array}$ & $\begin{array}{l}0(0.0 \\
\text { to } 1.1)\end{array}$ & $\begin{array}{l}0(0.0 \\
\text { to } 1.1)\end{array}$ \\
\hline Borghaei & 2015 & Nivolumab & 287 & $\begin{array}{l}0(0.0 \\
\text { to } 1.0)\end{array}$ & $\begin{array}{l}0(0.0 \\
\text { to } 1.0)\end{array}$ & $\begin{array}{l}16.4(12.3 \\
\text { to } 21.2)\end{array}$ & $\begin{array}{l}0.3(0.0 \\
\text { to } 1.9)\end{array}$ & $\begin{array}{l}12.9(9.2 \\
\text { to } 17.3)\end{array}$ & $\begin{array}{l}0.7(0.1 \\
\text { to } 2.5)\end{array}$ & $\begin{array}{l}13.6(9.8 \\
\text { to } 18.1)\end{array}$ & $\begin{array}{l}0.3(0.0 \\
\text { to } 1.9)\end{array}$ & $\begin{array}{l}12.2(8.6 \\
\text { to } 16.6)\end{array}$ & $\begin{array}{l}6.3(3.8 \\
\text { to } 9.7)\end{array}$ \\
\hline Brahmer & 2015 & Nivolumab & 131 & $\begin{array}{l}0(0.0 \\
\text { to } 2.3)\end{array}$ & $\begin{array}{l}0(0.0 \\
\text { to } 2.3)\end{array}$ & $\begin{array}{l}9.9(5.4 \\
\text { to } 16.4) \\
\end{array}$ & $\begin{array}{l}0(0.0 \\
\text { to } 2.3)\end{array}$ & $\begin{array}{l}9.9(5.4 \\
\text { to } 16.4) \\
\end{array}$ & $\begin{array}{l}0.8(0.0 \\
\text { to } 4.2)\end{array}$ & $\begin{array}{l}6.1(2.7 \\
\text { to } 11.7)\end{array}$ & $\begin{array}{l}0(0.0 \\
\text { to } 2.3)\end{array}$ & $\begin{array}{l}11.4(6.6 \\
\text { to } 18.2)\end{array}$ & $\begin{array}{l}6.1(2.7 \\
\text { to } 11.7)\end{array}$ \\
\hline Fehrenbacher & $2016 \ddagger$ & Atezolizumab & 141 & $\begin{array}{l}0(0.0 \\
\text { to } 2.1)\end{array}$ & $\begin{array}{l}0(0.0 \\
\text { to } 2.1)\end{array}$ & $\begin{array}{l}15.6(10.0 \\
\text { to } 22.7)\end{array}$ & $\begin{array}{l}2.1(0.4 \\
\text { to } 6.1)\end{array}$ & $\begin{array}{l}0(0.0 \\
\text { to } 2.1)\end{array}$ & $\begin{array}{l}0(0.0 \\
\text { to } 2.1)\end{array}$ & $\begin{array}{l}13.5(8.3 \\
\text { to } 20.2)\end{array}$ & $\begin{array}{l}1.4(0.2 \\
\text { to } 5.0)\end{array}$ & $\begin{array}{l}0(0.0 \\
\text { to } 2.1)\end{array}$ & $\begin{array}{l}0(0.0 \\
\text { to } 2.1)\end{array}$ \\
\hline Ferris & 2016 & Nivolumab & 236 & $\begin{array}{l}0(0.0 \\
\text { to } 1.3)\end{array}$ & $\begin{array}{l}0(0.0 \\
\text { to } 1.3)\end{array}$ & $\begin{array}{l}0(0.0 \\
\text { to } 1.3)\end{array}$ & $\begin{array}{l}0(0.0 \\
\text { to } 1.3)\end{array}$ & $\begin{array}{l}5.9(3.3 \\
\text { to } 9.8)\end{array}$ & $\begin{array}{l}0.9(0.1 \\
\text { to } 3.0)\end{array}$ & $\begin{array}{l}0(0.0 \\
\text { to } 1.3)\end{array}$ & $\begin{array}{l}0(0.0 \\
\text { to } 1.3)\end{array}$ & $\begin{array}{l}0(0.0 \\
\text { to } 1.3)\end{array}$ & $\begin{array}{l}0(0.0 \\
\text { to } 1.3)\end{array}$ \\
\hline \multirow[t]{2}{*}{ Herbst } & 2016 & $\begin{array}{l}\text { Pembrolizumab, } \\
2 \mathrm{mg} / \mathrm{kg}\end{array}$ & 338 & $\begin{array}{l}0.3(0.0 \\
\text { to } 1.6)\end{array}$ & $\begin{array}{l}0.3(0.0 \\
\text { to } 1.6)\end{array}$ & $\begin{array}{l}14.8(11.2 \\
\text { to } 19)\end{array}$ & $\begin{array}{l}0(0.0 \\
\text { to } 0.9)\end{array}$ & $\begin{array}{l}11.2(8.1 \\
\text { to } 15.1)\end{array}$ & $\begin{array}{l}0.6(0.1 \\
\text { to } 2.1)\end{array}$ & $\begin{array}{l}11.2(8.1 \\
\text { to } 15.1)\end{array}$ & $\begin{array}{l}0.6(0.1 \\
\text { to } 2.1)\end{array}$ & $\begin{array}{l}14.2(10.7 \\
\text { to } 18.4)\end{array}$ & $\begin{array}{l}7.4(4.8 \\
\text { to } 10.7) \\
\end{array}$ \\
\hline & & $\begin{array}{l}\text { Pembrolizumab, } \\
10 \mathrm{mg} / \mathrm{kg}\end{array}$ & 343 & $\begin{array}{l}0(0.0 \\
\text { to } 0.9)\end{array}$ & $\begin{array}{l}0(0.0 \\
\text { to } 0.9)\end{array}$ & $\begin{array}{l}12(8.7 \\
\text { to } 15.9)\end{array}$ & $\begin{array}{l}0.3(0.0 \\
\text { to } 1.6)\end{array}$ & $\begin{array}{l}12(8.7 \\
\text { to } 15.9)\end{array}$ & $\begin{array}{l}0.6(0.1 \\
\text { to } 2.1)\end{array}$ & $\begin{array}{l}9.9(7 \\
\text { to } 13.6)\end{array}$ & $\begin{array}{l}0(0.0 \\
\text { to } 0.9)\end{array}$ & $\begin{array}{l}14(10.5 \\
\text { to } 18.1)\end{array}$ & $\begin{array}{l}5(2.9 \\
\text { to } 7.8)\end{array}$ \\
\hline Langer & $2016 \ddagger$ & $\begin{array}{l}\text { Pembrolizumab, } \\
\text { combined§ }\end{array}$ & 59 & $\begin{array}{l}0(0.0 \\
\text { to } 5.1)\end{array}$ & $\begin{array}{l}0(0.0 \\
\text { to } 5.1)\end{array}$ & $\begin{array}{l}0(0.0 \\
\text { to } 5.1)\end{array}$ & $\begin{array}{l}0(0.0 \\
\text { to } 5.1)\end{array}$ & $\begin{array}{l}0(0.0 \\
\text { to } 5.1)\end{array}$ & $\begin{array}{l}0(0.0 \\
\text { to } 5.1)\end{array}$ & $\begin{array}{l}0(0.0 \\
\text { to } 5.1)\end{array}$ & $\begin{array}{l}0(0.0 \\
\text { to } 5.1)\end{array}$ & $\begin{array}{l}0(0.0 \\
\text { to } 5.1)\end{array}$ & $\begin{array}{l}0(0.0 \\
\text { to } 5.1)\end{array}$ \\
\hline Motzer & 2015 & Nivolumab & 406 & $\begin{array}{l}0(0.0 \\
\text { to } 0.7)\end{array}$ & $\begin{array}{l}0(0.0 \\
\text { to } 0.7)\end{array}$ & $\begin{array}{l}20.2(16.4 \\
\text { to } 24.4)\end{array}$ & $\begin{array}{l}0.5(0.1 \\
\text { to } 1.8)\end{array}$ & $\begin{array}{l}22.2(18.2 \\
\text { to } 26.5)\end{array}$ & $\begin{array}{l}1.7(0.7 \\
\text { to } 3.5)\end{array}$ & $\begin{array}{l}10.1(7.3 \\
\text { to } 13.5)\end{array}$ & $\begin{array}{l}0.2(0.0 \\
\text { to } 1.4)\end{array}$ & $\begin{array}{l}3.5(1.9 \\
\text { to } 5.7)\end{array}$ & $\begin{array}{l}9.6(6.9 \\
\text { to } 12.9)\end{array}$ \\
\hline Reck & $2016 \ddagger$ & Pembrolizumab & 154 & $\begin{array}{l}0(0.0 \\
\text { to } 1.9)\end{array}$ & $\begin{array}{l}0(0.0 \\
\text { to } 1.9)\end{array}$ & $\begin{array}{l}0(0.0 \\
\text { to } 1.9)\end{array}$ & $\begin{array}{l}0(0.0 \\
\text { to } 1.9)\end{array}$ & $\begin{array}{l}0(0.0 \\
\text { to } 1.9)\end{array}$ & $\begin{array}{l}0(0.0 \\
\text { to } 1.9)\end{array}$ & $\begin{array}{l}0(0.0 \\
\text { to } 1.9)\end{array}$ & $\begin{array}{l}0(0.0 \\
\text { to } 1.9)\end{array}$ & $\begin{array}{l}0(0.0 \\
\text { to } 1.9)\end{array}$ & $\begin{array}{l}0(0.0 \\
\text { to } 1.9)\end{array}$ \\
\hline \multirow[t]{2}{*}{ Ribas } & 2015 & $\begin{array}{l}\text { Pembrolizumab, } \\
2 \mathrm{mg} / \mathrm{kg}\end{array}$ & 178 & $\begin{array}{l}0(0.0 \\
\text { to } 1.7)\end{array}$ & $\begin{array}{l}0(0.0 \\
\text { to } 1.7)\end{array}$ & $\begin{array}{l}26.4(20.1 \\
\text { to } 33.5)\end{array}$ & $\begin{array}{l}0(0.0 \\
\text { to } 1.7)\end{array}$ & $\begin{array}{l}16.9(11.7 \\
\text { to } 23.2)\end{array}$ & $\begin{array}{l}0(0.0 \\
\text { to } 1.7)\end{array}$ & $\begin{array}{l}10.7(6.6 \\
\text { to } 16.2)\end{array}$ & $\begin{array}{l}0.6(0.0 \\
\text { to } 3.1)\end{array}$ & $\begin{array}{l}6.2(3.1 \\
\text { to } 10.8)\end{array}$ & $\begin{array}{l}12.4(7.9 \\
\text { to } 18.1)\end{array}$ \\
\hline & & $\begin{array}{l}\text { Pembrolizumab, } \\
10 \mathrm{mg} / \mathrm{kg}\end{array}$ & 179 & $\begin{array}{l}0(0.0 \\
\text { to } 1.7)\end{array}$ & $\begin{array}{l}0(0.0 \\
\text { to } 1.7)\end{array}$ & $\begin{array}{l}20(14.0 \\
\text { to } 26.1)\end{array}$ & $\begin{array}{l}1.1(0.1 \\
\text { to } 4.0)\end{array}$ & $\begin{array}{l}15.6(10.7 \\
\text { to } 21.8)\end{array}$ & $\begin{array}{l}1.1(0.1 \\
\text { to } 4.0)\end{array}$ & $\begin{array}{l}8.4(4.8 \\
\text { to } 13.4)\end{array}$ & $\begin{array}{l}0.6(0.0 \\
\text { to } 3.1)\end{array}$ & $\begin{array}{l}6.2(3.1 \\
\text { to } 10.7)\end{array}$ & $\begin{array}{l}7.8(4.3 \\
\text { to } 12.8)\end{array}$ \\
\hline Rittmeyer & $2017 \ddagger$ & Atezolizumab & 609 & $\begin{array}{l}0(0.0 \\
\text { to } 0.5)\end{array}$ & $\begin{array}{l}0(0.0 \\
\text { to } 0.5)\end{array}$ & $\begin{array}{l}12(9.5 \\
\text { to } 14.8)\end{array}$ & $\begin{array}{l}0.5(0.1 \\
\text { to } 1.4)\end{array}$ & $\begin{array}{l}11(8.6 \\
\text { to } 13.8)\end{array}$ & $\begin{array}{l}1.2(0.5 \\
\text { to } 2.4)\end{array}$ & $\begin{array}{l}10.5(8.2 \\
\text { to } 13.2)\end{array}$ & $\begin{array}{l}0.7(0.2 \\
\text { to } 1.7)\end{array}$ & $\begin{array}{l}14.9(12.2 \\
\text { to } 18.0)\end{array}$ & $\begin{array}{l}6.4(4.6 \\
\text { to } 8.7)\end{array}$ \\
\hline Robert & 2015 & Nivolumab & 206 & $\begin{array}{l}0(0.0 \\
\text { to } 1.5)\end{array}$ & $\begin{array}{l}0(0.0 \\
\text { to } 1.5)\end{array}$ & $\begin{array}{l}0(0.0 \\
\text { to } 1.5)\end{array}$ & $\begin{array}{l}0(0.0 \\
\text { to } 1.5)\end{array}$ & $\begin{array}{l}0(0.0 \\
\text { to } 1.5)\end{array}$ & $\begin{array}{l}0(0.0 \\
\text { to } 1.5)\end{array}$ & $\begin{array}{l}0(0.0 \\
\text { to } 1.5)\end{array}$ & $\begin{array}{l}0(0.0 \\
\text { to } 1.5)\end{array}$ & $\begin{array}{l}0(0.0 \\
\text { to } 1.5)\end{array}$ & $\begin{array}{l}0(0.0 \\
\text { to } 1.5)\end{array}$ \\
\hline Weber & 2015 & Nivolumab & 268 & $\begin{array}{l}0.4(0.0 \\
\text { to } 2.1)\end{array}$ & $\begin{array}{l}0.4(0.0 \\
\text { to } 2.1)\end{array}$ & $\begin{array}{l}23.1(18.2 \\
\text { to } 28.7)\end{array}$ & $\begin{array}{l}0.4(0.0 \\
\text { to } 2.1)\end{array}$ & $\begin{array}{l}21.6(16.9 \\
\text { to } 27.1)\end{array}$ & $\begin{array}{l}2.2 \text { (0.8 to } \\
4.8)\end{array}$ & $\begin{array}{l}11.9(8.3 \\
\text { to } 16.4)\end{array}$ & $\begin{array}{l}0 \text { (0.0 to } \\
1.1)\end{array}$ & $\begin{array}{l}3.7 \text { (1.8 to } \\
6.8)\end{array}$ & $\begin{array}{l}9.7(6.4 \\
\text { to } 13.9)\end{array}$ \\
\hline Total & NA & NA & 3803 & $\begin{array}{l}0.1(0.0 \\
\text { to } 0.2)\end{array}$ & $\begin{array}{l}0.1(0.0 \\
\text { to } 0.2)\end{array}$ & $\begin{array}{l}12.4(11.4 \\
\text { to } 13.5)\end{array}$ & $\begin{array}{l}0.3(0.2 \\
\text { to } 0.6)\end{array}$ & $\begin{array}{l}10.9(10.0 \\
\text { to } 12)\end{array}$ & $\begin{array}{l}0.8 \text { (0.6 to } \\
1.2)\end{array}$ & $\begin{array}{l}8.1 \text { (7.3 to } \\
9.0)\end{array}$ & $\begin{array}{l}0.3(0.2 \\
\text { to } 0.6)\end{array}$ & $\begin{array}{l}7.9 \text { (7.1 to } \\
8.8)\end{array}$ & $\begin{array}{l}5.6(4.8 \\
\text { to } 6.3)\end{array}$ \\
\hline
\end{tabular}

NA=not applicable.

*Includes both serious and other adverse events if data was extracted from ClinicalTrials.gov; includes all Common Terminology of Clinical Adverse Events (CTCAE) grades

if data was extracted from the publication.

tRepresents serious adverse events if data was extracted from ClinicalTrials.gov; represents CTCAE grades 3, 4, or 5 if data was extracted from the publication.

¥Study results were only taken from publication. No trial results were posted on ClinicalTrials.gov as of 28 March 2017.

$\S C$ mbined treatment included pembrolizumab, carboplatin, and pemetrexed.

ClinicalTrials.gov to collect more complete adverse event data than what was available in published trial reports, we were able to include adverse event data from ClinicalTrials.gov for only eight of 13 studies. However, it is unlikely that more publicly reported data would have substantially altered our findings. In addition, we combined all non-immunotherapy drugs into one control category, including both traditional chemotherapy and two targeted drugs, cetuximab and everolimus. We performed a subset analysis separating targeted from non-targeted control treatment. Risks of pneumonitis and rash differ for targeted treatments compared with traditional chemotherapy and odds ratios differed across control treatments, so targeted drugs are presented separately. For other outcomes there was no heterogeneity based on comparator so all studies are presented together. Finally, we pooled data from studies that used different anti-PD-1 drugs at variable doses so we may have missed differences in adverse event rates across drugs or based on dosage differences. Given the wide variation in drug and dose across studies we were unable to perform subgroup analyses to examine these factors. However, we found little heterogeneity across studies for adverse event outcomes, suggesting little difference based on the specific drug or dose.

\section{Unanswered questions and future research}

Our study provides insight into the adverse events from treatment with anti-PD-1 drugs, which have revolutionized care for patients with cancer in the last few years. We found that anti-PD-1 drugs are more likely than standard treatments to cause pneumonitis, colitis, rash, and hypothyroidism but not fatigue or diarrhea. We also found variable reporting of musculoskeletal problems, with high rates in some studies, suggesting that anti-PD-1 drugs likely do cause some bone, muscle, and joint adverse events. However, owing to the short interval of follow-up data currently available from clinical trials and a lack of clarity in the systematic capture of many adverse events, we are likely to have underestimated the true rates of adverse events. Moving forward, longer term follow-up and specific attention to a variety of immune-related adverse events may enhance our understanding. Until then, for the practicing clinician, our findings suggest the importance of monitoring all adverse events in patients treated with anti-PD-1 drugs. 


\section{Conclusions}

We found that the risk of organ specific immunerelated adverse events such as hypothyroidism, colitis, and perhaps pneumonitis are increased with anti-PD-1 drugs compared with standard treatments although overall event rates remain low. In contrast, compared with control arms, the risk of general adverse events related to immune activation, such as fatigue and diarrhea, are not increased. Further, we found that antiPD-1 drugs seem to lead to musculoskeletal problems such as arthralgia, back pain, musculoskeletal pain, and myalgia, that can negatively impact quality of life and long term tolerability of immotherapy, though reporting of these adverse events was inconsistent.

Contributors: All authors had full access to the data in the study and can take responsibility for the integrity of the data and the accuracy of the data analysis. DK is the guarantor.

Funding: This study was supported in part by the National Institutes of Health and National Cancer Institute Cancer Center Support Grant (P30 CA008748). The funder had no role in the design of the study; the collection, analysis, and interpretation of the data; or approval of the finished manuscript.

Competing interests: All authors have completed the ICMJE uniform disclosure form at www.icmje.org/coi_disclosure.pdf and declare: no support from any organization for the submitted work; no financial relationships with any organisations that might have an interest in the submitted work in the previous three years; no other relationships or activities that could appear to have influenced the submitted work.

Ethical approval: Not required.

Data sharing: No additional data are available.

Transparency: The lead author (SB) affirms that the manuscript is an honest, accurate, and transparent account of the study being reported; that no important aspects of the study have been omitted; and that any discrepancies from the study as planned (and, if relevant, registered) have been explained.

This is an Open Access article distributed in accordance with the Creative Commons Attribution Non Commercial (CC BY-NC 4.0) license, which permits others to distribute, remix, adapt, build upon this work non-commercially, and license their derivative works on different terms, provided the original work is properly cited and the use is noncommercial. See: http://creativecommons.org/licenses/by-nc/4.0/.

1 IMS Institute for Healthcare Informatics. Global Use of Medicines: Outlook through 2017. 2017. http://www.quotidianosanita.it/ allegati/allegato1501906.pdf

2 Abdel-Rahman O, ElHalawani H, Fouad M. Risk of gastrointestinal complications in cancer patients treated with immune checkpoint inhibitors: a meta-analysis. Immunotherapy 2015;7:1213-27. 10.2217/imt.15.87

3 De Velasco G, Je Y, Bossé D, et al. Comprehensive Meta-analysis of Key Immune-Related Adverse Events from CTLA-4 and PD-1/PD-L1 Inhibitors in Cancer Patients. Cancer Immunol Res 2017;5:312-8. 10.1158/2326-6066.CIR-16-0237

4 Abdel-Wahab N, Shah M, Suarez-Almazor ME. Adverse Events Associated with Immune Checkpoint Blockade in Patients with Cancer: A Systematic Review of Case Reports. PLoS One 2016;11:e0160221. 10.1371/journal.pone.0160221

5 Abdel-Rahman O, Helbling D, Schmidt J, et al. Treatment-associated Fatigue in Cancer Patients Treated with Immune Checkpoint Inhibitors; a Systematic Review and Meta-analysis. Clin Oncol (R Coll Radiol) 2016;28:e127-38. 10.1016/j.clon.2016.06.008

6 Abdel-Rahman O, Fouad M. A network meta-analysis of the risk of immune-related renal toxicity in cancer patients treated with immune checkpoint inhibitors. Immunotherapy 2016;8:665-74. 10.2217/ imt-2015-0020

7 Abdel-Rahman O, Fouad M. Risk of pneumonitis in cancer patients treated with immune checkpoint inhibitors: a meta-analysis. Ther Adv Respir Dis 2016:10:183-93. 10.1177/1753465816636557

8 Abdel-Rahman O, ElHalawani H, Fouad M. Risk of elevated transaminases in cancer patients treated with immune checkpoint inhibitors: a meta-analysis. Expert Opin Drug Saf 2015;14:1507-18. 10.1517/14740338.2015.1085969

9 Cappelli LC, Shah AA, Bingham CO 3rd. Cancer immunotherapyinduced rheumatic diseases emerge as new clinical entities. RMD Open 2016;2:e000321. 10.1136/rmdopen-2016-000321
10 Cappelli LC, Gutierrez AK, Baer AN, et al. Inflammatory arthritis and sicca syndrome induced by nivolumab and ipilimumab. Ann Rheum Dis 2017;76:43-50. 10.1136/annrheumdis-2016-209595

11 Moher D, Liberati A, Tetzlaff J, Altman DG, Group P. Preferred reporting items for systematic reviews and meta-analyses: the PRISMA statement. Ann Intern Med . 2009:151:264-9.10.7326/0003-4819151-4-200908180-00135

12 Bramer WM, Giustini D, de Jonge GB, Holland L, Bekhuis T. Deduplication of database search results for systematic reviews in EndNote. J Med Libr Assoc 2016;104:240-3. 10.3163/ 1536-5050.104.3.014

13 Higgins JP, Altman DG, Gøtzsche PC, et al, Cochrane Bias Methods Group, Cochrane Statistical Methods Group. The Cochrane Collaboration's tool for assessing risk of bias in randomised trials. BMJ 2011;343:d5928. 10.1136/bmi.d5928

14 Herbst RS, Baas P, Kim DW, et al. Pembrolizumab versus docetaxel for previously treated, PD-L1-positive, advanced non-smallcell lung cancer (KEYNOTE-010): a randomised controlled trial. Lancet 2016;387:1540-50. 10.1016/S0140-6736(15)01281-7

15 Ribas A, Puzanov I, Dummer R, et al. Pembrolizumab versus investigator-choice chemotherapy for ipilimumab-refractory melanoma (KEYNOTE-002): a randomised, controlled, phase 2 trial. Lancet Oncol 2015;16:908-18. 10.1016/S1470-2045(15)00083-2

16 Borghaei H, Paz-Ares L, Horn L, et al. Nivolumab versus Docetaxel in Advanced Nonsquamous Non-Small-Cell Lung Cancer. N Engl J Med 2015;373:1627-39. 10.1056/NEJMoa1507643

17 Brahmer J, Reckamp KL, Baas P, et al. Nivolumab versus Docetaxel in Advanced Squamous-Cell Non-Small-Cell Lung Cancer. N Engl J Med 2015;373:123-35. 10.1056/NEJMoa1504627

18 Motzer RJ, Escudier B, McDermott DF, et al, CheckMate 025 Investigators. Nivolumab versus Everolimus in Advanced RenalCell Carcinoma. N Engl J Med 2015;373:1803-13. 10.1056/ NEIMoa1510665

19 Robert C, Long GV, Brady B, et al. Nivolumab in previously untreated melanoma without BRAF mutation. N Engl J Med 2015;372:320-30. 10.1056/NEJMoa1412082

20 Weber JS, D’Angelo SP, Minor D, et al. Nivolumab versus chemotherapy in patients with advanced melanoma who progressed after anti-CTLA-4 treatment (CheckMate 037): a randomised, controlled, open-label, phase 3 trial. Lancet Oncol 2015;16:375-84. 10.1016/S1470-2045(15)70076-8

21 Fehrenbacher L, Spira A, Ballinger M, et al, POPLAR Study Group. Atezolizumab versus docetaxel for patients with previously treated non-small-cell lung cancer (POPLAR): a multicentre, open-label, phase 2 randomised controlled trial. Lancet 2016;387:1837-46. 10.1016/S0140-6736(16)00587-0

22 Ferris RL, Blumenschein G Jr, Fayette J, et al. Nivolumab for Recurrent Squamous-Cell Carcinoma of the Head and Neck. N Engl J Med 2016:375:1856-67. 10.1056/NEIMoa1602252

23 Langer CJ, Gadgeel SM, Borghaei H, et al, KEYNOTE-021 investigators. Carboplatin and pemetrexed with or without pembrolizumab for advanced, non-squamous non-small-cell lung cancer: a randomised, phase 2 cohort of the open-label KEYNOTE-021 study. Lancet Oncol 2016;17:1497-508. 10.1016/S1470-2045(16)30498-3

24 Reck M, Rodríguez-Abreu D, Robinson AG, et al, KEYNOTE-024 Investigators. Pembrolizumab versus Chemotherapy for PD-L1Positive Non-Small-Cell Lung Cancer. N Engl I Med 2016;375: 1823-33. 10.1056/NEJMoa1606774

25 Bellmunt J, de Wit R, Vaughn DJ, et al, KEYNOTE-045 Investigators. Pembrolizumab as Second-Line Therapy for Advanced Urothelial Carcinoma. N Engl J Med 2017;376:1015-26. 10.1056/ NEIMoa1613683

26 Rittmeyer A, Barlesi F, Waterkamp D, et al, OAK Study Group. Atezolizumab versus docetaxel in patients with previously treated non-small-cell lung cancer (OAK): a phase 3, open-label, multicentre randomised controlled trial. Lancet 2017;389:255-65. 10.1016/ S0140-6736(16)32517-X

27 Komaki Y, Komaki F, Yamada A, Micic D, Ido A, Sakuraba A. Meta-analysis of the risk of immune-related adverse events with anticytotoxic T-lymphocyte-associated antigen 4 and antiprogrammed death 1 therapies. Clin Pharmacol Ther 2018;103:318-31. 10.1002/cpt.633

28 Richtel M. Immune System, Unleashed by Cancer Therapies, Can Attack Organs. New York Times [Internet]; 2016. https://www. nytimes.com/2016/12/03/health/immunotherapy-cancer.html

29 Weber JS, Yang JC, Atkins MB, Disis ML. Toxicities of Immunotherapy for the Practitioner. J Clin Oncol 2015;33:2092-9. 10.1200/ ICO.2014.60.0379

30 Ritchlin CT, Colbert RA, Gladman DD. Psoriatic Arthritis. N EnglJ Med 2017:376:957-70. 10.1056/NEJMra1505557

31 Cappelli LC, Gutierrez AK, Bingham CO 3rd, Shah AA. Rheumatic and musculoskeletal immune-related adverse events due to immune checkpoint inhibitors: A systematic review of the literature. Arthritis Care Res (Hoboken) . 2017;69:1751-63. 10.1002/acr.23177 
32 Cappelli LC, Shah AA, Bingham CO 3rd. Immune-Related Adverse Effects of Cancer Immunotherapy- Implications for Rheumatology. Rheum Dis Clin North Am 2017;43:65-78. 10.1016/j. rdc.2016.09.007

33 Christ L, Mönch S, Hasmann S, et al. FRI0606 Characteristics and treatment of new onset arthritis after checkpoint inhibitor therapy. Ann Rheum Dis 2017;76(Suppl 2):718.

34 Kostine M, Rouxel L, Barnetche T, et al. Rheumatic disorders associated with immune checkpoint inhibitors in patients with cancer-clinical aspects and relationship with tumour response: a single-centre prospective cohort study. Ann Rheum Dis 2018:77:393-8. 10.1136/annrheumdis-2017-212257

35 Anvik T, Holtedahl KA, Mikalsen H. "When patients have cancer, they stop seeing me"--the role of the general practitioner in early follow-up of patients with cancer--a qualitative study. BMC Fam Pract 2006;7:19. 10.1186/1471-2296-7-19

36 Uyl-de Groot CA, Brouwer WBF, de Maeseneer JM, Verweij J. Primary care in cancer control: towards mature cancer care. Lancet Oncol 2015:16:1226-7. 10.1016/S1470-2045(15)00294-6

37 Weber JS, Postow M, Lao CD, Schadendorf D. Management of Adverse Events Following Treatment With Anti-Programmed Death-1 Agents. Oncologist 2016;21:1230-40. 10.1634/ theoncologist.2016-0055

38 Linardou H, Gogas H. Toxicity management of immunotherapy for patients with metastatic melanoma. Ann Transl Med 2016;4:272. 10.21037/atm.2016.07.10

39 Umscheid CA, Margolis DJ, Grossman CE. Key concepts of clinical trials: a narrative review. Postgrad Med 2011;123:194-204. 10.3810/pgm.2011.09.2475
40 Belkhir R, Burel SL, Lambotte O, et al. OP0004 Rheumatoid arthritis occuring after immune checkpoint inhibitors. Ann Rheum Dis 2017;76(Suppl 2):1747-50. 10.1136/ annrheumdis-2017-211216

41 Larkin J, Chmielowski B, Lao CD, et al. Neurologic Serious Adverse Events Associated with Nivolumab Plus Ipilimumab or Nivolumab Alone in Advanced Melanoma, Including a Case Series of Encephalitis. Oncologist 2017;22:709-18. 10.1634/ theoncologist.2016-0487

42 Zimmer L, Goldinger SM, Hofmann L, et al. Neurological, respiratory, musculoskeletal, cardiac and ocular side-effects of anti-PD-1 therapy. Eur J Cancer 2016;60(Supplement C):210-25. 10.1016/j. ejca.2016.02.024

43 Läubli H, Balmelli C, Bossard M, Pfister O, Glatz K, Zippelius A. Acute heart failure due to autoimmune myocarditis under pembrolizumab treatment for metastatic melanoma. / Immunother Cancer 2015;3:11. 10.1186/s40425-015-0057-1

44 Johnson DB, Balko JM, Compton ML, et al. Fulminant Myocarditis with Combination Immune Checkpoint Blockade. N Engl] Med 2016;375:1749-55. 10.1056/NEJMoa1609214

45 Saini P, Loke YK, Gamble C, Altman DG, Williamson PR, Kirkham JJ. Selective reporting bias of harm outcomes within studies: findings from a cohort of systematic reviews. BMJ 2014;349:g6501. 10.1136/bmj.g6501

\section{Appendix: Supplementary materials}

